\title{
Planning the reorganization of territories with dilapidated housing stock for social infrastruc- ture: case study of Perm, Russia
}

\author{
Nelly Shaldunova ${ }^{1}$, Nadezhda Denisova $^{1}$, Olga Starenkova $^{1}$, David Seturidze ${ }^{1}$, and Marina \\ Podkovyrova, ${ }^{2, *}$ \\ ${ }^{1}$ Perm State Agrarian and Technological University, 614990, Perm city, Russia \\ ${ }^{2}$ Industrial University of Tyumen, 625001, Tyumen city, Russia
}

\begin{abstract}
Multi-storey residential development is rapidly developing in Russian cities, both point-by-point, through the consolidation of existing buildings, and through the organization of new residential neighborhoods due to the integrated development of territories. Complex development of the territory involves the construction of not only residential buildings, but also objects of social and engineering infrastructure: kindergartens, schools, shops, sports facilities, parking lots, landscaping of yard spaces with the use of landscape architecture objects. At the same time, the architectural appearance of the development area is being worked out, and a favorable ecological and aesthetically attractive urban environment is being created [1]. However, the presence of old dilapidated buildings causes a number of problems that require a comprehensive analysis, covering the economic, social, regulatory and legal aspects to solve them. The article deals with the problems of placing social infrastructure objects in different types of urban development. It is proposed to use the territory with a dilapidated housing stock for the development of social infrastructure. Its expediency is justified.
\end{abstract}

\section{Introduction}

Practice shows that most of the projects of integrated development of the territory are implemented on the outskirts of cities, since the city center is a formed part of it, in which new houses appear as a result of compaction of existing buildings, or as a renovation of old neighborhoods.

In turn, the outskirts of cities are an attractive area for the implementation of complex development projects. As for the principles of integrated development of territories, they were also applied in the Soviet period in the construction of military and industrial cities to a greater extent (at industrial enterprises (factories, woodworking plants, etc.), all infrastructure was necessarily built, residential quarters were formed, kindergartens, schools, clinics, etc. were built).

\footnotetext{
* Corresponding author: podkovyrova.54@mail.ru
} 
Russian scientists emphasize that the urban housing market largely depends on the number of available sites for construction. Currently, there are trends of urban sprawl at the expense of suburban areas, that is, at the expense of agricultural land [2].

In recent decades, spot construction has been widely used in Russian cities, by compacting or demolishing the existing housing stock; " there is a tendency to reuse builtup areas, usually occupied by dilapidated and dilapidated buildings that are subject to demolition or liquidation. Thus, the use of built-up areas allows you to get new free sites, increase the area of development and increase the indicators of the introduction of new housing stock" [3].

For a long time, the demolition of dilapidated housing was not carried out, and if it occurred, it was on a small scale, since it was economically unjustified. Since the adoption of Article 32 of the Housing Code of the Russian Federation of 29.12.2004, the processes of demolition of dilapidated housing stock in the central districts of cities and the renovation of entire blocks have begun [4]. On the one hand, this allowed us to change the architectural appearance of cities, especially its central districts, to remove dilapidated, unsightly buildings and build new ones, and on the other hand, to increase the burden on the municipal, transport and social infrastructure. Considering a large metropolis or a provincial town, you can distinguish blocks with different periods of development. For example, in the city of Perm, residential buildings can be divided into several groups according to the time of their construction (Table 1).

Table 1. Grouping of apartment buildings in the city of Perm, taking into account the year of construction for the period 1919-2018.

\begin{tabular}{|c|c|c|c|c|}
\hline Groups & $\begin{array}{c}\text { Year of } \\
\text { construction }\end{array}$ & $\begin{array}{c}\text { Number of } \\
\text { houses }\end{array}$ & $\begin{array}{c}\text { Number of } \\
\text { apartments. } \\
\text { units }\end{array}$ & $\begin{array}{c}\text { Living area. } \\
\text { thousand sq. } \mathbf{~ m}\end{array}$ \\
\hline I & $1919-1939$ & 139 & 1617 & 115.66 \\
\hline II & $1940-1959$ & 1214 & 20332 & 1139.54 \\
\hline III & $1960-1979$ & 2085 & 136443 & 9030.03 \\
\hline IV & $1980-1999$ & 849 & 81385 & 4577.04 \\
\hline V & $2000-2018$ & 482 & 50229 & 3112.71 \\
\hline \multicolumn{2}{r}{ Total } & 4769 & 290006 & 17974.98 \\
\hline
\end{tabular}

It should be emphasized that each time period contributed to the architectural appearance of Perm:

1. The first group is characterized by the fact that after 1917 , the time came for the restoration of enterprises destroyed by the Civil War, the development of urban centers: the Central Hotel was built, the buildings of the city executive committee, the post office and the Melody store were built. The thirties left the city with buildings in the constructivist style.

2. The second group reflects the nature of the development:

- during the Great Patriotic War, residential areas grew up near evacuated enterprises (for example: the microdistricts of Krokhalevka, Krasnova, Vladimirsky);

- in the fifties (the time of a kind of "Stalinist Empire"), residential buildings were built along Komsomolsky Prospekt.

3. The third group reflects the "era" of the famous "Khrushchevki", which were built on the principle of minimum costs while providing the population with a large number of wellarranged housing, public buildings, cultural institutions in fast-growing cities, as evidenced by statistical data (Table 1). However, the acceleration in solving these problems has led to standardization, uniformity in housing construction, planning and construction of streets and cities in general. 
4. The fourth group covers the period starting from the $80 \mathrm{~s}$, when the construction of nine-storey residential buildings, new residential districts at industrial enterprises begins. In the early $90 \mathrm{~s}$, there is a demand for luxury housing in the city center.

5. The beginning of the XXI century (the fifth group) - the time of new construction trends. The traditions of "wild" construction are gradually giving way to well-thought-out solutions that allow the buildings to be built to fit seamlessly into the natural urban landscape [5].

Along with the new housing stock, many buildings that are more than 70 years old remain in the city. Aging of buildings occurs for various reasons of wear and tear: physical, moral and aesthetic. To date, federal and regional programs have been adopted to demolish the dilapidated housing stock in order to improve the living conditions of Russians. However, at the same time, the issues of providing residential development with social infrastructure facilities, such as kindergartens and schools, are not always fully worked out.

The works of Russian scientists: Grabovoi P. G., Kharitonov V. A., Ivanov N. N., Belyakov S. I., Averyanov V. K. and others are devoted to the problems of the long-term development of built-up areas, providing them with engineering infrastructure, reconstruction, demolition of dilapidated and emergency housing. [1, 2, 3, 6, 11-14, 19]. In the context of the modern nature of urbanization, a number of issues require further research.

\section{Materials and methods}

The purpose of this study is to study the processes of point development of the territory with apartment buildings and the allocation of land plots for the placement of social infrastructure facilities. In this regard, the main advantages and disadvantages of the development of the built-up area for housing construction are determined; the size and location of land plots for the missing social infrastructure facilities.

The authors of the article consider the development and placement of land plots for the objects of social infrastructure in the case of point residential development on the example of the Industrial district of the city of Perm.

Perm is a large industrial city in the Western Urals, located on the Kama River, which is the administrative center of the Perm Region. According to Rosstat, as of 01.01.2019, more than 1053.9 thousand people live in it. The territory of the city of Perm includes seven districts: Dzerzhinsk, Industrialny, Kirovsky, Leninsky, Motovilikhinsky, Ordzhonikidzevsky and Sverdlovsk, which are intra-city administrative divisions. The industrial district is located in the south-western part of the city, on the territory of which a number of large industrial enterprises operate, such as: LUKOIL-Permnefteorgsintez LLC, Sibur-Himprom JSC, Novomet-Perm JSC, PPF - a branch of Goznak JSC and others. The area of the district is 6265.0 ha. The main part of the territory of the study area is occupied by industrial land (1898.0 ha); residential and public-business development land is 1592.0ha [7].

On the territory of the district there are 932 apartment buildings, the private sector is represented by almost 1800 individual houses. The total area of the housing stock is more than 3 million 881 thousand square meters. m. Since 2016, the Industrial District has been actively building new housing in the Decembrist and No-Voplosky microdistricts.

According to the results of the work of the interdepartmental commission under the administration of the Industrial District as of 01.01.2018: 64 apartment buildings were recognized as emergency, residential premises in 21 houses were recognized as unsuitable for living. 
The total area of dilapidated housing stock in the Industrial District was 37,727 sq. m (Table 2).

Table 2. The number and volume of residential premises deemed unfit for habitation and emergency apartment buildings in the Industrial district of Perm.

\begin{tabular}{|l|c|c|c|c|c|}
\hline \multirow{2}{*}{ Funds } & \multirow{2}{*}{$\begin{array}{c}\text { Number of } \\
\text { objects }\end{array}$} & $\begin{array}{c}\text { Total area of a residential } \\
\text { building or apartment } \\
\text { building, sq. m }\end{array}$ & \multicolumn{3}{|c|}{ Number } \\
\cline { 4 - 6 } & 64 & 32640 & 662 & 1649 & 660 \\
\hline $\begin{array}{l}\text { Emergency } \\
\text { housing stock }\end{array}$ & 64 & 5087 & 211 & 145 & 211 \\
\hline $\begin{array}{l}\text { Unsuitable } \\
\text { housing stock }\end{array}$ & 21 & 37727 & 873 & 1794 & 871 \\
\hline Result: & 85 & people & rooms \\
\hline
\end{tabular}

A lot of emergency housing is located in Novoplosky and Balatovsky microdistricts, Figure 1 .

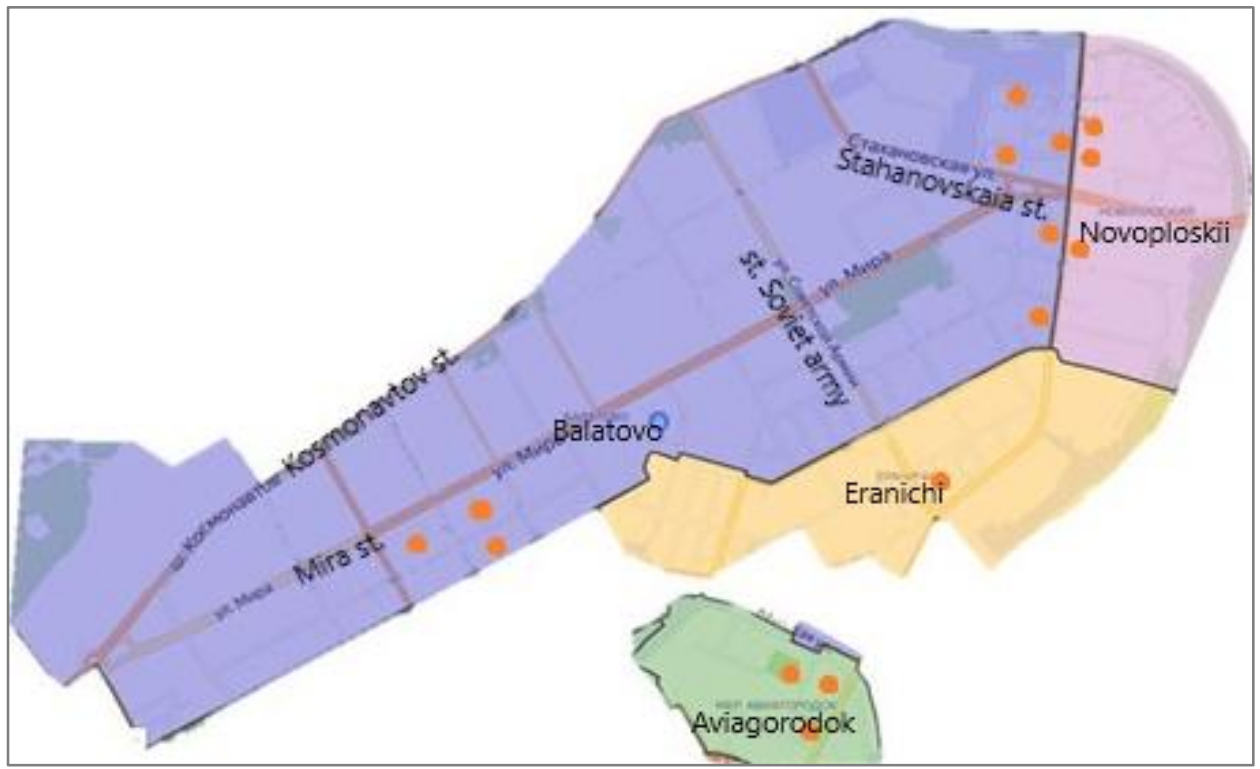

Fig. 1. Placement of emergency housing in an industrial area.

The location of the dilapidated housing stock to be settled on the territory of the Balatovo - Novoplosky, Yeranichi microdistricts is shown in Figure 2. Most of the land plots of the dilapidated housing stock are located along Karpinsky Street, the total area of which is 6.8 hectares. The total area of the dilapidated housing stock in the Yeranichi microdistrict is 1.4 hectares. 

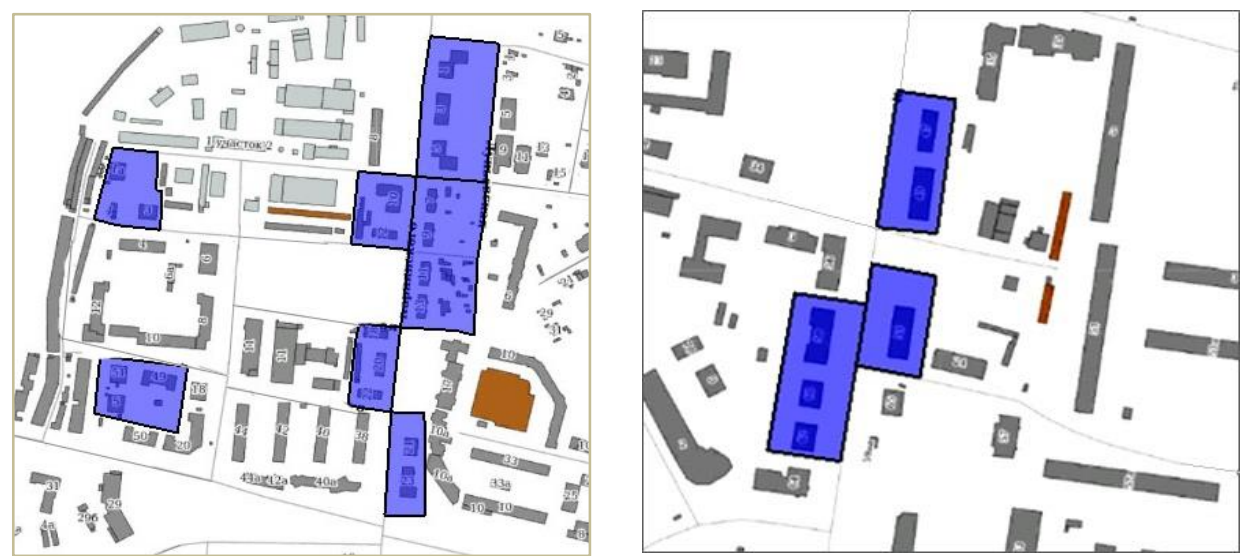

Fig. 2. Placement of dilapidated housing stock in micro districts Balatovo-Novoplosky, Yeranichi (fragment).

The study showed that within the quarter of the Aviagorodok microdistrict, with an area of 3.3 hectares, there is an accumulation of dilapidated housing stock (Figure 3). Dilapidated housing in the Balatovo microdistrict is located along the streets of Neftyanikov and Cosmonaut Belyaev, the total area of land plots is 2.2 hectares (Figure 3).

The total area under the dilapidated housing stock in the Industrial District is 13.7 hectares. The settlement is carried out within the framework of the Departmental target program "Resettlement of citizens of the city of Perm from the emergency housing stock". In their place, it is planned to build high-rise apartment buildings, which will significantly affect the demographic situation in the district and increase the burden on the social infrastructure.
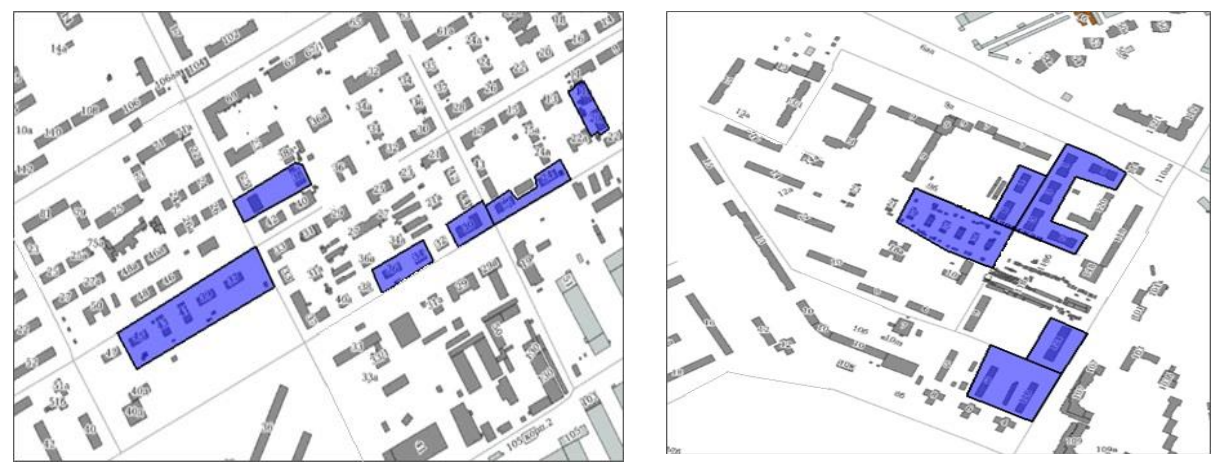

Fig. 3. Placement of dilapidated housing stock in the micro districts of Aviagorodok, Balatovo (fragment).

The statistical analysis of the population of the city of Perm showed that the demographic situation in the last 10-15 years has undergone significant changes. In recent decades, these processes have been alarming, with periods of significant population decline, but these trends have been corrected. The permanent population of the city of Perm has been steadily increasing since 2009. This is due to both migration and natural growth (Table 3, Figure 4 [17]. 
Table 3. Dynamics of the permanent population of the city of Perm in the period from 2005 to 2019 *.

\begin{tabular}{|c|c|c|c|c|c|c|c|c|}
\hline \multirow{2}{*}{ Indicator } & \multicolumn{7}{|c|}{ Years } \\
\cline { 2 - 8 } & $\mathbf{2 0 0 5}$ & $\mathbf{2 0 0 7}$ & $\mathbf{2 0 0 9}$ & $\mathbf{2 0 1 1}$ & $\mathbf{2 0 1 3}$ & $\mathbf{2 0 1 5}$ & $\mathbf{2 0 1 7}$ & $\mathbf{2 0 1 9}$ \\
\hline $\begin{array}{c}\text { Permanent } \\
\text { population } \\
\text { size, } 01.01, \\
\text { thousands of } \\
\text { people }\end{array}$ & 998 & 990 & 985 & 991 & 1013 & 1036 & 1048 & 1053 \\
\hline
\end{tabular}

* Statistical data of Permstat [Electronic resource]: Territorial body of the Federal State Statistics Service for the Perm Region (Permstat). - Access mode:

http://permstat.gks.ru/wps/wcm/connect/rosstat_ts/permstat/ru/statistics/population/

As of January 1, 2019, the permanent population was 1051583 people, or $100.34 \%$ compared to the previous year (an increase of 3578 people). Thus, the trend towards an increase in the number of permanent population remains, therefore, the population's need for housing will increase.

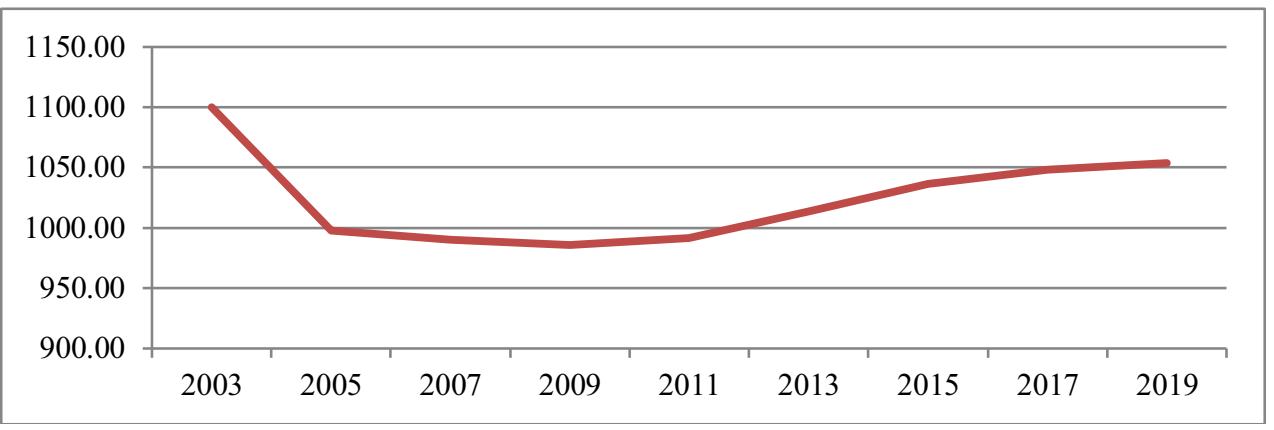

Fig. 4. Dynamics of the permanent population of the city of Perm (2003-2019 years).

The increase in the population, both in the city and in the districts, is accompanied by growing tension in the sphere of providing the population with social infrastructure facilities. In this regard, its further development is required, which includes measures for the construction and acquisition of social infrastructure facilities into municipal ownership. The need for these measures is determined on the basis of indicators of the population's provision with objects of preschool, general and additional education, and culture.

The housing market in the city is developing due to the development of large apartment buildings, including houses that are built on the site of residential buildings that are recognized as habitable and unfit for habitation. Let's take the typical 22-storey residential buildings that are being built today in the city of Perm with spot construction. The living area in the house is 29165 sq. m, the land area is 9465.0 sq. m. The calculation of the prospective number of people living in this house determined the need for social infrastructure facilities in the future.

According to Permstat, the total area of residential premises per person in the city of Perm is 23.6 sq. $\mathrm{m} /$ person [17]. Taking into account the area of land plots under the dilapidated housing stock in the microdistricts, an increase in the population was determined. The estimated population for residential apartment buildings is calculated using the formula 1 :

$$
\mathrm{N}=\mathrm{F} / \mathrm{a},
$$

where $\mathrm{N}$ is the number of future residents in new houses, people;

$\mathrm{F}$ - the area of the housing stock under construction in microdistricts, sq. m.;

a-the indicator of the provision of the population with a total area, sq. m/person. 
The area of the housing stock planned on the site of emergency housing will be about 203 thousand square meters, while the population will increase by 8,600 people. Table 4 shows the calculations of the population in the context of microdistricts.

Table 4. Calculation of the population of multi-apartment residential buildings located on land plots with dilapidated housing stock.

\begin{tabular}{|l|c|c|c|c|}
\hline $\begin{array}{c}\text { Neighborhood } \\
\text { s with } \\
\text { dilapidated } \\
\text { residential } \\
\text { buildings }\end{array}$ & $\begin{array}{c}\text { Area under } \\
\text { dilapidated } \\
\text { housing } \\
\text { stock/number of } \\
\text { houses }\end{array}$ & $\begin{array}{c}\text { Housing stock } \\
\text { area. sq.m }\end{array}$ & $\begin{array}{c}\text { Average provision } \\
\text { rate of the } \\
\text { population with a } \\
\text { total area. sq. } \\
\text { m/person }\end{array}$ & $\begin{array}{c}\text { Estimated } \\
\text { population. } \\
\text { people }\end{array}$ \\
\hline $\begin{array}{l}\text { Novoploskiy- } \\
\text { Balatovo }\end{array}$ & $3.4 / 3$ & 81000 & & 3432 \\
\hline Aviagorodok & $1.2 / 2$ & 54000 & \multirow{2}{*}{23.6} & 2288 \\
\hline Yeranichi & $0.4 / 1$ & 14000 & & 592 \\
\hline Balatovo & $1.2 / 2$ & 54000 & & 2288 \\
\hline \multicolumn{1}{r|}{ Total } & $6.2 / 8$ & 203000 & & 8600 \\
\hline
\end{tabular}

The number of children of preschool and school-age children living in multi-apartment residential buildings are defined according to the statistical data, with-according to which, the proportion of children up to 18 years in the city of Perm, equal to, or $21.0 \%$, and the structure by sex and age group is children from 1 to 7 years of $50.5 \%$, from 8 to 18 years $49.5 \%$ (table 5).

Table 5. Calculation of the number of preschool and school-age children living in multi-apartment residential buildings located on land plots with dilapidated housing stock.

\begin{tabular}{|l|c|c|c|c|}
\hline \multirow{2}{*}{ Structure indicators } & \multirow{2}{*}{$\begin{array}{c}\text { Population } \\
\text { in the housing } \\
\text { stock }\end{array}$} & \multicolumn{3}{|c|}{$\begin{array}{c}\text { Number of children } \\
\text { population. people }\end{array}$} \\
\cline { 3 - 5 } & 8600 & 1-7 years & 8-18 years & Total \\
\hline Number of people & 100.0 & & & 1806 \\
\hline $\begin{array}{l}\text { Proportion of children. as a } \\
\text { percentage of the total } \\
\text { population. \% }\end{array}$ & & & & 21.0 \\
\hline $\begin{array}{l}\text { Percentage from the child } \\
\text { population. \% }\end{array}$ & 50.5 & 49.5 & 100 \\
\hline
\end{tabular}

Table 5 shows that the number of children in the microdistricts will increase. According to the Perm city administration, the shortage of places in kindergartens is from 2 to $4 \%$, and in schools children are engaged in 2 shifts. Based on this, the need for social infrastructure facilities was calculated (Table 6).

Table 6. Calculation of the number of social facilities for the population of multi-apartment residential buildings located on land plots with dilapidated housing stock.

\begin{tabular}{|c|c|c|c|c|c|c|}
\hline & \multirow{2}{*}{$\begin{array}{c}\text { Estimated } \\
\text { Mopulation, } \\
\text { people }\end{array}$} & \multicolumn{4}{|c|}{$\begin{array}{c}\text { Estimated number of } \\
\text { children, pers. }\end{array}$} & $\begin{array}{c}\text { Capacity of planned } \\
\text { social facilities } \\
\text { capacity/ number of } \\
\text { objects) }\end{array}$ \\
\cline { 3 - 7 } & & Total & $\begin{array}{c}1-7 \\
\text { years }\end{array}$ & $\begin{array}{c}\mathbf{8}-\mathbf{1 8} \\
\text { years }\end{array}$ & $\begin{array}{c}\text { kinderg } \\
\text { artens }\end{array}$ & schools \\
\hline Novoploskiy & 3432 & 720 & 364 & 356 & $300 / 1$ & - \\
\hline Aviagorodok & 2288 & 481 & 243 & 238 & $300 / 1$ & $750 / 1$ \\
\hline Yeranichi & 592 & 124 & 63 & 61 & - & - \\
\hline Balatovo & 2288 & 481 & 242 & 239 & $300 / 1$ & $340 / 1$ \\
\hline Total & 8600 & 1806 & 912 & 894 & & \\
\hline
\end{tabular}


To accommodate the necessary social infrastructure facilities, new vacant land plots are required, but, based on the fact that their availability is limited, we propose in some cases, instead of multi-storey buildings on land plots with dilapidated housing stock, to place social infrastructure facilities (kindergartens and schools). The construction of social facilities instead of apartment buildings on land plots with dilapidated housing stock will reduce the population in microdistricts, improve their social attractiveness, activate the housing market, and solve a number of other problems.

\section{Results}

When According to the calculations carried out, it was established that additional land plots for the construction of kindergartens should be allocated in the territory of the Novoplosky, Aviagorodok, and Balatovo microdistricts. In the microdistricts of Balatovo and Aviagorodok, land plots are required to accommodate schools. There is a particularly acute shortage of schools in the Yeranichi microdistrict. Based on the fact that in some microdistricts, the need for space is less than the volume of typical buildings, it is proposed to study land plots on the borders of neighboring microdistricts. At the same time, it is taken into account that the radius of servicing preschool institutions is no more than 300 meters, and general education schools - no more than 500 meters [9].

The size of land plots for one place for preschool institutions and general education schools is established in accordance with the capacity of institutions in accordance with the Code of Rules of SP 42.13330.2016 "Urban planning. Planning and development of urban and rural settlements" [9].

According to the calculations carried out, in order to meet the growing demand of the population for social infrastructure facilities in the Industrial area, it is necessary to build:

1) Three kindergartens in the microdistricts: Novoplosky, Aviagorodke, Balatova with a total capacity of 300 seats. For the construction of these facilities, an area of 3.15 hectares will be required.

2) Two schools: one on the territory of the Aviagorodok microdistrict with coverage of new buildings in the Eranichi and Balatovo microdistricts (along Karpinsky Street), the second-in the Balatova microdistrict (along Neftyanikov Street). For construction, it is necessary to allocate two land plots with a total area of 4.36 hectares (Table 7, Figure 5, 6).

Table 7. Calculation of the area of land plots for social infrastructure objects.

\begin{tabular}{|c|c|c|c|c|c|}
\hline Microdistrict & 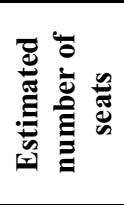 & 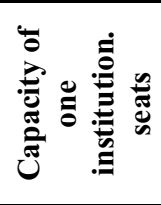 & 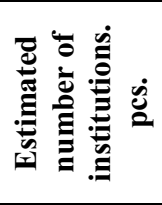 & 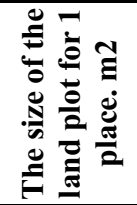 & 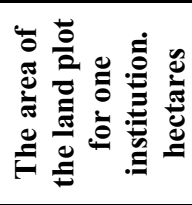 \\
\hline \multicolumn{6}{|c|}{ Kindergartens } \\
\hline Novoploskiy & 364 & 300 & 1 & \multirow{4}{*}{35} & 1.05 \\
\hline Aviagorodok & 243 & 300 & 1 & & 1.05 \\
\hline Yeranichi & 63 & - & - & & \\
\hline Balatovo & 242 & 300 & 1 & & 1.05 \\
\hline Total & 912 & 900 & 3 & & 3.15 \\
\hline \multicolumn{6}{|c|}{ Schools } \\
\hline $\begin{array}{l}\text { Aviagorodok } \\
\text { (coverage } \\
\text { Yeranichi. } \\
\text { Novoploskiy) }\end{array}$ & 655 & 750 & 1 & \multirow[t]{2}{*}{40} & 3.0 \\
\hline Balatovo & 239 & 340 & 1 & & 1.36 \\
\hline Total & 894 & 1090 & 2 & & 4.36 \\
\hline
\end{tabular}



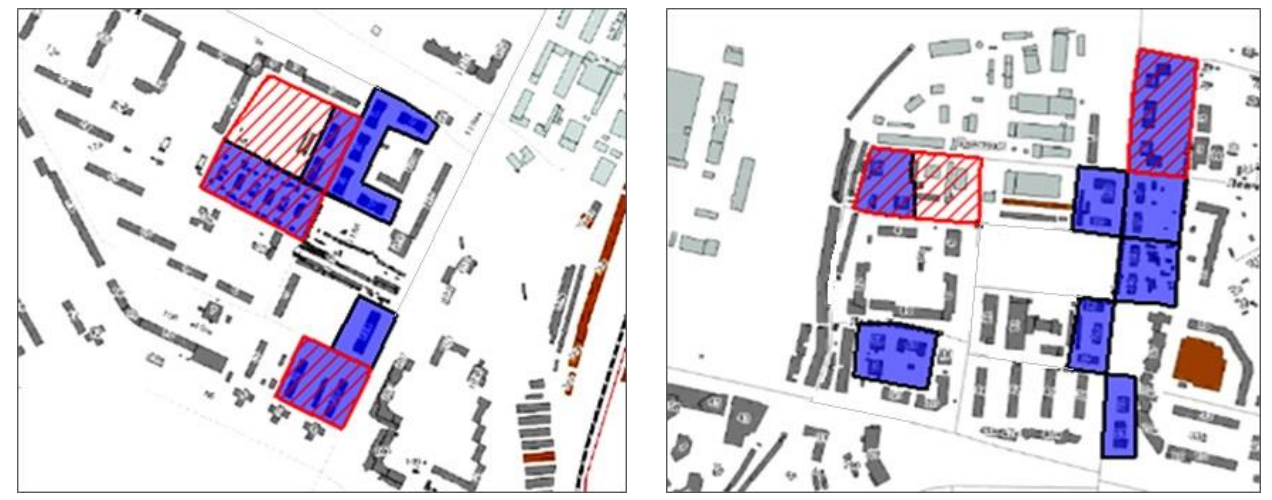

Fig. 5. Placement of social infrastructure objects in microdistricts Balatovo-Novopolotsk, Aviagorodok.

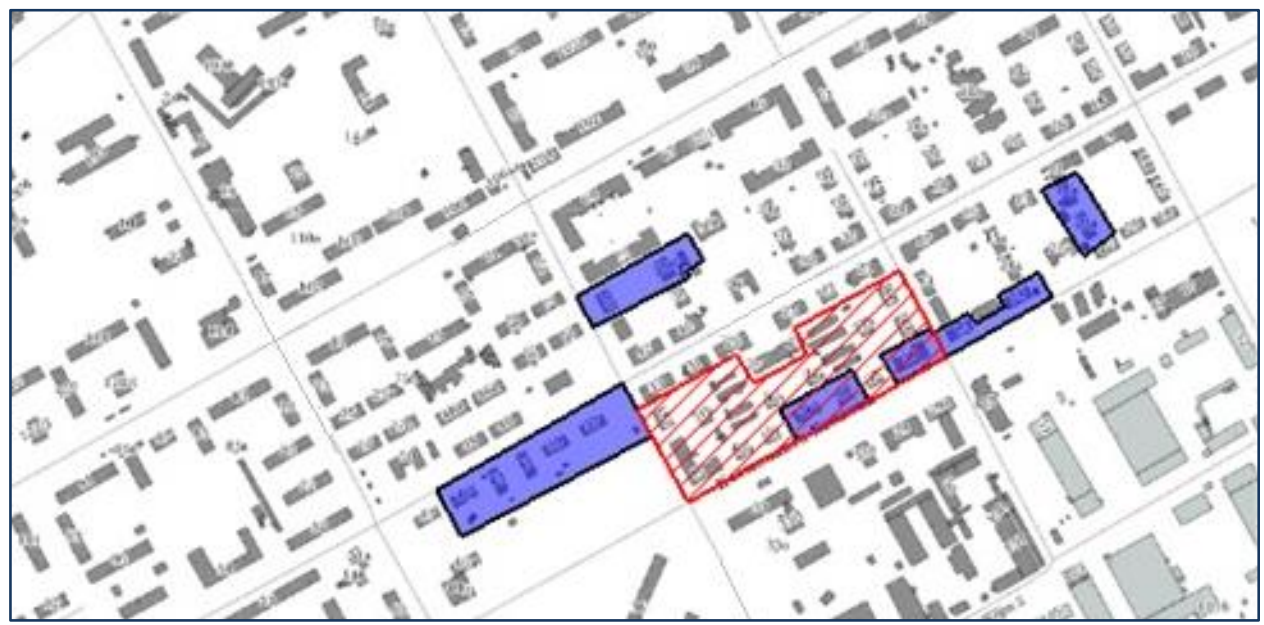

Fig. 6. Placement of social infrastructure facilities in the Balatovo microdistrict.

\section{Discussion}

Planning the development of social infrastructure is one of the main tasks for the development of territories for housing construction and requires finding the optimal balance in the ratio of residential buildings and objects of social significance, ensuring the comfort of living for people [15]. If the complex development of the territory of the project provides for the construction of various infrastructure - social, engineering, then with a point, these issues require thorough study.

The developer is mainly interested in a specific land plot for the construction of the object and the possibility of connecting to engineering networks. All other issues are problems of local self-government bodies. Undoubtedly, there is a legal and urban planning documentation, however, being developed for a long time, it does not always take into account the rapid changes in existing realities, so it requires correction $[5,17,19]$. 


\section{Conclusion}

Our research has proved the need to take into account the needs of the developed territory in additional social infrastructure facilities. The analysis of the development of the built-up area for housing construction due to the demolition of dilapidated housing revealed the pros and cons.

Cons:

1. Significant financial costs: the developer, when using land plots with dilapidated housing stock, bears significant costs for the settlement of residents. The costs of settlement and construction of facilities (buildings) are borne by the budgets of municipalities.

The calculation of the costs for the construction of the missing social infrastructure facilities in the city of Perm is based on the average cost of the construction of social infrastructure facilities in the Perm Region for 2017. The cost of one place in a kindergarten is 722.6 thousand rubles, and one place in a school is one million rubles. The construction of additional social infrastructure facilities will cost the city 1.7 billion rubles. It should be noted that the construction of preschool institutions and schools is a long-term plan and requires targeted funding.

2. Architectural requirements: the dilapidated housing stock is located in an already existing building, often these territories have historical value, their architectural appearance and the developer needs to preserve it, and this is an additional cost.

3. Environmental requirements: when placing social facilities, it is necessary to take into account such factors as the suitability of the territories, taking into account noise, electromagnetic and other environmental impacts on the territory (the proximity of major highways, railways, power lines, industrial facilities).

Positive:

1. Issues of providing the population with housing stock, places in kindergartens, schools, taking into account pedestrian and transport accessibility, are resolved.

2. The social attractiveness of the territories is created, the housing market is activated.

3. The level of comfort of living of the population in the territory increases.

The solution to this problem requires a detailed study not only from the economic point of view, but also from the legal point of view, it is necessary to prescribe the procedure for making adjustments to the construction documentation, and to adopt additional legal documents by local self-government bodies.

\section{References}

1. E. Galinovskaya, Property relations in the Russian Federation 1, 44-49 (2012)

2. N. Shaldunova, Cetverte internacionalne konferencije ekonomskog fakulteta Brcko «Perspeektive partnerstva vlasti, privrede i instiiucija visokog obrasovanja u podsticanju ekonomskog razvoja 10, 171 - 177 (2018)

3. Ya. Fayzrakhmanova, Management of the development of built-up territories. Abstract for the dissertation of the Candidate of Economic Sciences (Penza State University of Architecture and Construction, 2015)

4. Housing Code of the Russian Federation. Federal Law 188-FZ (2004) https : //base.garant.ru/ 12138291

5. About the approval of the General plan of the city of Perm. Decision of the Perm City Duma 205 (2010) https : //base.garant.ru/ 16175358

6. V. Averyanov, S. Bulgakov, S. Chistovich, Industrial and civil construction 2, 51-55 (1997) 
7. R. Aliev, Science and business: ways of development 6, 94-101 (2018)

8. S. Belyakov, K. Efimov,International Scientific and Technical Journal Immobility: economics, management 1, 82-87 (2018)

9. P. Grabovoy, V. Kharitonov, Reconstruction and renewal of the existing city development

http://books.totalarch.com/reconstruction_and_renovation_of_the_existing_building_o f_the_city

10. N. Ivanov, Bulletin of Civil Engineers 2, 174-177 (2015)

11. A. Krasheninnikov, Urban development of residential development: a study of the experience of Western countries http://books.totalarch.com/urban_development_of_residential

(2005)

12. G. Lukyanenko, Agrarian and land law 10, 46-48 (2008)

13. K. Mingaleeva, V. Moor, Architecture and design: history, theory, innovation 1, 188192 (2016)

14. M. Podkovyrova, O. Volobueva, L. Gilyova, E3S Web of Conferences 110, 02114 (2019)

15. A.N. Ponosov, N.N. Zhernakova, B. Drashkovich, International Scientific Research Journal (2017) http://nauka-prioritet.ru/

16. N. Shaldunova, N. Denisova, Forecasting and planning the use of urban territories: an educational and methodological manual (2014)

17. About the approval of the rules of land use and development of the city of Perm. Decision of the Perm City Duma 143 (2007) https: //base.garant.ru/ 14312138258

18. M. Podkovyrova, A. Oleynik, A. Matveeva, E. Ivanenko, Fundamentals of urban planning and planning of populated places: textbook, https://search.rsl.ru/ru/record/01008573745

19. Urban Planning Code of the Russian Federation: Federal Law 29/12/2004 190-FZ, https : //base.garant.ru/ 12138258 